\title{
GAMBARAN PENGETAHUAN IBU HAMIL DALAM PENCEGAHAN PENYAKIT ANEMIA DI DESA KWALA BEGUMIT KABUPATEN LANGKAT
}

\author{
Nixson Manurung \\ Universitas Imelda Medan, Jl. Bilal No. 52 Kelurahan Pulo Brayan Darat I Kecamatan Medan Timur, \\ Medan - Sumatera Utara. \\ Email : nixsonmanurung@gmail.com
}

\begin{abstract}
ABSTRAK
Anemia pada saat hamil adalah anemia karena kekurangan zat besi. Ini merupakan bagian dari berbagai anemia yang pengobatanya mudah dan murah. Anemia pada saat kehamilan menjadi masalah nasional karena menggambarkan nilai-nilai kesejahteraan sosial ekonomi masarakat dan pengaruhnya sangat berperan terhadap kualitas sumber daya manusia (Manuaba, 2010). Pengetahuan ibu hamil perihal kesehatannya terutama perihal anemia sangat berpengaruh pada perilaku ibu hamil pada saat melaksanakan program pencegahan anemia dan sikap tersebut dapat berupa tanggapan. Umumnya Ibu hamil sering mengalami kekurangan zat besi hingga hanya bisa memberi sedikit besi kepada janin yang dibutuhkan dalam proses metabolisme besi yang normal. Penelitian ini bertujuan untuk memberi gambaran pemahaman ibu hamil dalam pencegahan penyakit anemia di Desa Kwala Begumit Kabupaten Langkat. Jenis penelitian yang digunakan dalam penelitian ini adalah jenis penelitian Deskriptif. Tehnik sampling yang digunakan dalam penelitian ini menggunakan tehnik probability sampling dan jumlah sampel dalam penelitian ini berjumlah 68 keluarga di Desa Kwala Begumit Kabupaten Langkat periode Januari-Maret 2019. Tehnik Analisa data yang digunakan adalah editing, coding, sorting, entry data dan cleaning. Hasil penelitian mayoritas usia responden berumur 21 - 40 tahun yaitu 47 orang $(69,22 \%)$ sedangkan responden yang berumur 12 - 25 Tahun sebanyak 21 orang (30,88\%), dan responden yang berumur 41 - 50 tahun tidak ditemui, responden dengan pendidikan SD sebanyak 27 orang (39,7 \%), SLTP sebanyak 28 orang (41,1\%), SLTA dan D3/S1/Sederajat masing-masing sebanyak 7 orang (10,1 $\%)$, sumber informasi diperoleh melalui tenaga kesehatan sebanyak 22 orang (32,4\%), Kerabat/Keluarga sebanyak 18 orang (26,4\%), Media cetak sebanyak 12 orang (17,6\%) dan melalui Media elektronik berjumlah 16 orang (23,6\%), mayoritas pekerjaan ibu hanya sebagai IRT berjumlah 29 orang (42,6\%), Bertani berjumlah 21 orang (30,9\%), Wiraswasta berjumlah 15 orang (22,1\%) dan PNS berjumlah 3 orang (4,4\%), mayoritas tingkat pengetahuan responden cukup berjumlah 34 orang (50 \%), sedangkan berpengetahuan baik hanya 20 orang $(29,4 \%)$ dan yang berpengetahuan buruk sebanyak 14 orang (20, 6 $\%)$. Dari penelitian ini bisa disimpulkan bahwa pemahaman ibu hamil di Desa Kwala Begumit ini terkategori cukup dikaitkan dengan media informasi yang masih kurang ditandai dengan terbatasnya sarana pelayanan kesehatan yang berpusat di Puskesmas Desa Kwala Begumit untuk dipergunakan oleh 15 dusun yang ada di desa ini. Namun, keterbatasan fasilitas dan tingkat pendidikan menjadi salah satu faktor penghambat seorang ibu hamil untuk mendapatkan pengetahuan yang baik dan menentukan sikap yang baik dalam pencegahan penyakit anemia.
\end{abstract}

Kata Kunci : Ibu Hamil, Anemia, Pencegahan

ABSTRACT

Anemia during pregnancy is anemia due to iron deficiency. This is part of various anemia treatments that are easy and inexpensive. Anemia during pregnancy becomes a national problem because it illustrates the values of socio-economic well-being of the community and their influence greatly affects the quality of human resources (Manuaba, 2010). Knowledge of pregnant women about their health, especially regarding anemia is very influential on the behavior of pregnant women when implementing an anemia prevention program and that attitude can be a response. Generally, pregnant women often experience iron deficiency so they can only give a little iron to the fetus needed in the process of normal iron metabolism. This study aims to illustrate the understanding of pregnant women in the prevention of anemia in the village of Kwala Begumit, Langkat Regency. This type of research used in this research is descriptive research type. The sampling technique used in this study uses probability sampling techniques and the number of samples in this study amounted to 68 families in the Kwala Begumit Village, Langkat Regency in the January-March 2019 period. Data analysis techniques used were editing, coding, sorting, data entry and cleaning. The results of the majority of respondents aged 21-40 years are 47 people (69.22\%) while respondents aged 12-25 years were 21 people (30.88\%), and respondents aged 41-50 years were not found, respondents with 27 elementary school education (39.7\%), 28 junior high school 
students (41.1\%), senior high school and D3 / S1 / equivalents as many as 7 people (10.1\%), sources of information obtained through as many health workers 22 people (32.4\%), Relatives / Family 18 people (26.4\%), Print media 12 people (17.6\%) and through electronic media 16 people (23.6\%), the majority of mothers work only as IRT with 29 people (42.6\%), Agriculture with 21 people (30.9\%), Entrepreneurs with 15 people $(22.1 \%)$ and civil servants with 3 people $(4.4 \%)$, the majority of respondents' knowledge level only 34 people (50\%), while only 20 people (29.4\%) have good knowledge and 14 people (20, 6\%) have poor knowledge. From this study it can be concluded that the understanding of pregnant women in the Kwala Begumit Village is categorized as quite related to the information media which is still lacking marked by the limited health care facilities centered at the Kwala Begumit Village Health Center for use by 15 hamlets in this village. However, limited facilities and education levels are one of the factors preventing a pregnant woman from getting good knowledge and determining a good attitude in preventing anemia.

Keywords: Pregnant Women, Anemia, Prevention

\section{PENDAHULUAN}

Kekurangan darah atau disebut juga dengan anemia pada proses kehamilan merupakan anemia karena kekurangan zat besi. Ini bagian dari jenis anemia yang pengobatannya masih mudah dan murah. Anemia atau kekurangan darah di kehamilan merupakan masalah nasional karena mencerminkan nilai kesejahteraan sosial ekonomi masarakat dan pengaruhnya sangat besar terhadap kualitas sumber daya manusia (Manuaba, 2010).

Anemia defisiensi besi merupakan bentuk anemia yang paling umum. Sekitar $20 \%$ wanita, $50 \%$ wanita hamil dan $3 \%$ dari pria tidak punya cukup zat besi dalam tubuh mereka. Besi merupakan bagian hemoglobin, yang dapat merupakan protein pembawa oksigen dalam darah. Tanpazatbesi darah tidak dapat membawa oksigen secara efektif (Atikah, 2011).

Pemberian informasi tentang anemia harus diberikan sehingga pengetahuan mereka tentang anemia menjadi lebih baik, karena pengetahuan memegang peranan yang sangat penting sehingga ibu hamil patuh meminum zat besi. Rendahnya pendidikan ibu akan berdampak pada rendahnya pengetahuan ibu yang berpengaruh pada keputusan ibu untuk mendapatkan pelayanan kesehatan. Makin rendah pengetahuan ibu, makin sedikit keinginannya untuk memanfaatkan pelayanan kesehatan. Pendidikan ibu adalah faktor yang cukup berpengaruh terhadap terjadinya anemia (BKKBN, 2001). Angka anemia kehamilan di Indonesia menunjukkan nilai yang cukup tinggi. How Swie Tjioeng menemukan angka anemia kehamilan 3,8\% pada trimester I, $13,6 \%$ pada trimester II, dan $24,8 \%$ pada trimester III. Akrib Sukarman
(2008), menemukan sebesar 40,1\% di Bogor. Bakta, (2011) menemukan 50,7\% di Puskesmas kota Denpasar sedangkan Sindu, (2011) menemukan $70 \%$ ibu hamil di Indonesia menderita anemia kurang gizi (Purwanto, 2008).

Penelitian sebelumnya yang berkaitan dengan pemberian tablet zat besi (fe) dengan kejadian anemia pada ibu hamil menyatakan bahwa ibu hamil yang mengalami kejadian anemia atau defisiensi zat besi menyebabkan ibu mengalami gejala lemah, lesu, pusingpusing, dan pucat. Setelah ibu hamil mengkonsumsi zat besi sebagian besar ibu mengalami perubahan yang sebelumnya anemi menjadi tidak anemia lagi (Hutagaol, 2017).

Selain itu, penelitian terdahulu yang berjudul Tingkat Pengetahuan Ibu Hamil Tentang Manfaat Zat Besi (Fe) Pada Kehamilan Trimester Dua Di Puskesmas Alooa Gunung Sitoli Medan menyatakan anemia yang terjadi pada ibu berdampak ke janin kemungkinan anak mengalami berat badan lahir rendah hingga prematur (Silalahi \& Hulu, 2019).

Dari survey awal yang dilakukan di desa kwala begumit pada ibu rumah tangga khususnya ibu hamil. mereka menyatakan bahwa beberapa mereka sering mengalami pusing dan setelah melakukan pemeriksaan oleh peneliti dari beberapa ibu disana bahwa mayoritas ibu disana mengalami hipotensi atau rendahnya tekanan darah. Kemudian peneliti melakukan survey kepuskesmas bahwa penyakit anemia berada pada peringkat kedua penyakit sering dialami ibu hamil, faktor penyebab masalah ini terjadi karena kurangnya pengetahuan, serta sikap disebabkan ibu hamil tidak berusaha untuk memperoleh informasi tentang bahaya 
anemia pada ibu hamil dan informasi penyebab terjadinya penyakit anemia. Dampak yang ditimbulkan apabila ibu tidak pencegahan pada penyakit anemia akan berdampak terhadap kematian pada saat persalinan dan menyebabkan BBLR pada bayi.

\section{METODE}

Penelitian dalam studi ini menggunakan jenis penelitian Deskriptif yang bertujuan mengetahui gambaran pengetahuan ibu hamil dalam pencegahan penyakit anemia di Desa Kwala Begumit Kabupaten Langkat Penelitian ini dilaksanakan di Desa Kwala Begumit Kabupaten Langkat.

Waktu pelaksanaan penelitian ini akan dilaksanakan pada bulan Juni s/d Juli bulan tahun 2019. Jumlah sampel yang terkumpul dalam penelitian ini berjumlah 68 keluarga. Tehnik Analisa data yang digunakan adalah editing, coding, sorting, entry data dan cleaning.

\section{HASIL}

Tabel 1. Distribusi Frekuensi Responden

Berdasarkan Umur ibu hamil dalam pencegahan penyakit anemia di Desa Kwala Begumit Kabupaten Langkat Tahun 2019.

\begin{tabular}{cccc}
\hline No & Umur & Skor & Persentase (\%) \\
\hline 1 & $12-20$ Tahun & 21 & 30,88 \\
\hline 2 & $21-40$ Tahun & 47 & 69,22 \\
\hline 3 & $41-50$ Tahun & 0 & 0 \\
\hline & TOTAL & $\mathbf{6 8}$ & $\mathbf{1 0 0 \%}$ \\
\hline
\end{tabular}

Dari tabel 1 diatas dapat dilihat bahwa mayoritas usia responden berumur 21-40 Tahun sebanyak 47 orang $(69,22 \%)$ sedangkan responden yang berumur $12-25$ Tahun sebanyak 21 orang $(30,88 \%)$, dan responden yang berumur 41 - 50 Tahun tidak ditemui

Tabel 2. Distribusi Frekuensi Responden Berdasarkan Pendidikan ibu hamil dalam pencegahan penyakit anemia di Desa Kwala Begumit Kabupaten Langkat Tahun 2019.

\begin{tabular}{cccc}
\hline No & Pendidikan & Skor & Persentase (\%) \\
\hline 1 & SD & 27 & 39,7 \\
\hline 2 & SLTP & 28 & 41,1 \\
\hline 3 & SLTA & 7 & 10,1 \\
\hline 4 & D3/S1/Sederajat & 7 & 10,1 \\
\hline & TOTAL & $\mathbf{6 8}$ & $\mathbf{1 0 0 \%}$ \\
\hline
\end{tabular}

Dari tabel 2 diatas dapat dilihat responden yang berpendidikan SD berjumlah 27 orang $(39,7 \%)$, SLTP berjumlah 28 orang
$(41,1 \%)$, SLTA dan D3/S1/Sederajat masing-masing berjumlah 7 orang $(10,1 \%)$.

Tabel 3. Distribusi Frekuensi Responden Berdasarkan sumber informasi ibu hamil dalam pencegahan penyakit anemia di Desa Kwala Begumit Kabupaten Langkat Tahun 2019.

\begin{tabular}{cccc}
\hline No & $\begin{array}{c}\text { Sumber } \\
\text { Informasi }\end{array}$ & Skor & Persentase (\%) \\
\hline 1 & $\begin{array}{c}\text { Tenaga } \\
\text { kesehatan }\end{array}$ & 22 & 32,4 \\
\hline 2 & Kerabat/keluarga & 18 & 26,4 \\
\hline 3 & Media cetak & 12 & 17,6 \\
\hline 4 & Media elektronik & 16 & 23,6 \\
\hline & TOTAL & $\mathbf{6 8}$ & $\mathbf{1 0 0 \%}$ \\
\hline
\end{tabular}

Dari tabel 3 diatas dapat dilihat 68 responden, mayoritas memperoleh sumber informasi melalui Tenaga kesehatan berjumlah 22 orang $(32,4 \%)$, Kerabat/Keluarga berjumlah 18 orang $(26,4 \%)$, Media cetak berjumlah 12 orang $(17,6 \%)$ dan melalui Media elektronik berjumlah 16 orang $(23,6 \%)$.

Tabel 4. Distribusi Frekuensi Responden Berdasarkan Pekerjaan ibu hamil dalam pencegahan penyakit anemia di Desa Kwala Begumit Kabupaten Langkat Tahun 2019.

\begin{tabular}{cccc}
\hline No & Pekerjaan & Skor & Persentase (\%) \\
\hline 1 & IRT & 29 & 42,6 \\
\hline 2 & Bertani & 21 & 30,9 \\
\hline 3 & Wiraswasta & 15 & 22,1 \\
\hline 4 & PNS & 3 & 4.4 \\
\hline & TOTAL & $\mathbf{6 8}$ & $\mathbf{1 0 0 \%}$ \\
\hline
\end{tabular}

Dari tabel 4 diatas dapat dilihat dari 68 responden mayoritas pekerjaan ibu hanya sebagai IRT berjumlah 29 orang $(42,6 \%)$, Bertani berjumlah 21 orang $(30,9 \%)$, Wiraswasta berjumlah 15 orang $(22,1 \%)$ dan PNS berjumlah 3 orang $(4,4 \%)$.

Tabel 5. Distribusi frekuensi pengetahuan ibu hamil dalam pencegahan penyakit anemia di Desa Kwala Begumit Kabupaten Langkat Tahun 2019.

\begin{tabular}{cccc}
\hline No & Pengetahuan & Frekuensi & $\begin{array}{c}\text { Persentase } \\
(\mathbf{\%})\end{array}$ \\
\hline 1 & Baik & 20 & 29,4 \\
\hline 2 & Cukup & 34 & 50 \\
\hline 3 & Buruk & 14 & 20.6 \\
\hline & TOTAL & $\mathbf{6 8}$ & $\mathbf{1 0 0}$ \\
\hline
\end{tabular}

Berdasarkan tabel diatas dapat dilihat mayoritas tingkat pengetahuan responden cukup berjumlah 34 orang (50\%), sedangkan 
berpengetahuan baik hanya 20 orang $(29,4 \%)$ dan yang berpengetahuan buruk berjumlah 14 orang $(20,6 \%)$.

\section{PEMBAHASAN}

Pengetahuan Ibu Hamil Tentang Pencegahan Penyakit Anemia di Desa Kwala Begumit Kabupaten Langkat. Menunjukkan bahwa dari 68 ibu hamil yang menjadi responden menunjukkan bahwa mayoritas tingkat pengetahuan responden cukup berjumlah 34 orang (50\%), sedangkan berpengetahuan baik hanya 20 orang $(29,4 \%)$ dan yang berpengetahuan buruk berjumlah 14 orang $(20,6 \%)$.

Peneliti berasumsi bahwa hal ini dipengaruhi oleh usia responden yang mayoritasnya berumur 21-40 tahun sebanyak 47 orang $(69,22 \%)$ sesuai dengan teori Notoadmodjo (2010). Usia mempengaruhi terhadap daya tangkap daya dan pola pikir seseorang semakin bertambah usia akan semakin berkembang pula daya tangkap dan pola pikirnya, sehingga pengetahuan yang di perolehnya semakin membaik. faktor lain ditambahkan mayoritas responden memperoleh sumber informasi kesehatan diperoleh langsung melalui Tenaga kesehatan hanya berjumlah 22 orang $(32,4 \%)$ saja ditambah mayoritas pekerjaan ibu hanya sebagai IRT berjumlah 29 orang $(42,6 \%)$, Bertani berjumlah 21 orang $(30,9 \%)$, Wiraswasta berjumlah 15 orang $(22,1 \%)$ dan PNS berjumlah 3 orang $(4,4 \%)$. Pengetahuan selain bersumber dari pendidikan dan pengamanan juga berasal dari sumber informasi yang didapatnya. Seseorang masyarakat didalam proses pendidikan juga dapat memperoleh pengetahuan dari berbagai macam alat bantu I media (BKKBN, 2005). Sesuai dengan teori Notoadmojo (2010) adapun faktor - faktor yang mempengaruhi pengetahuan (usia, sosial dan budaya, media informasi, pendidikan, pengalaman dan lingkungan) disini peneliti membandingkan hasil penelitian dengan teori yang ada.

Peneliti dapat menyimpulkan bahwa pengetahuan ibu hamil di desa kwala begumit ini terkategori cukup dikaitkan dengan media informasi yang masih kurang ditandai dengan terbatasnya sarana pelayanan kesehatan yang berpusat di Puskesmas Desa Kwala Begumit untuk dipergunakan oleh 15 dusun yang ada di desa ini.

Namun, keterbatasan vasilitas dan tingkat pendidikan menjadi salah satu faktor penghambat seorang ibu hamil untuk mendapatkan pengetahuan yang baik dan menentukan sikap yang baik dalam pencegahan penyakit anemiahal ini terlihat dari hasil penelitian ditemukan SD berjumlah 27 orang $(39,7 \%)$, SLTP berjumlah 28 orang $(41,1 \%)$, SLTA dan D3/S1/Sederajat masing-masing berjumlah 7 orang $(10,1 \%)$. Disini sangatlah penting peranan tenaga kesehatan untuk meningkatkan pengetahuan ibu hamil dengan memberikan pendidikan tentang penyakit anemia dan pencegahannya (BKKN, 2005).

\section{KESIMPULAN}

Peneliti dapat menyimpulkan bahwa pengetahuan ibu hamil di desa kwala begumit ini terkategori cukup dikaitkan dengan media informasi yang masih kurang ditandai dengan terbatasnya sarana pelayanan kesehatan yang berpusat di Puskesmas Desa Kwala Begumit untuk dipergunakan oleh 15 dusun yang ada di desa ini. Namun, keterbatasan fasilitas dan tingkat pendidikan menjadi salah satu faktor penghambat seorang ibu hamil untuk mendapatkan pengetahuan yang baik dan menentukan sikap yang baik dalam pencegahan penyakit anemia.

\section{DAFTAR PUSTAKA}

Admina. 2008. Anemia Pada Kehamilan. Dikutip pada tanggal 25 april 2011 jam 14.30 wib dari http://Danicherblogspot.com.

Angreini, D. 2009. Persiapan Dan Perawatan Kemahilan. Pustaka Bunda :Yogyakarta.

Astria,Y. $2009 . \quad$ Keperawatan Maternitas.Graha Ilmu:Yogyakarta.

Budiyanto. 2005. Anemia Pada Kehamilan. Salemba Medika: Jakarta.

Dinkes. 2005. Indonesi Berkomitmen Turunkan Angk Kematian Ibu Dan Anak Dikutip Pada Tanggal 27 april 2011 jam 11.20 wib dari http:// Writen.

Erfandi.2008. Anemia pada Ibu Hamil. Dikutip pada tanggal 20 april 2011 jam 11.30 wib dari http:// Puskesmas-oke blogspot,com.

Hutagaol, A. (2017). Hubungan pemberian 
tablet zat besi dengan anemia pada ibu hamil di Klinik Deli Tua Tahun 2008. Jurnal Ilmiah Keperawatan Imelda, 3(1), $1-7$. http://jurnal.uimedan.ac.id/index.php/JU RNALKEPERAWATAN/article/view/2 $52 / 255$

Silalahi, B., \& Hulu, dian herawati. (2019). TINGKAT PENGETAHUAN IBU HAMIL TENTANG MANFAAT ZAT BESI (Fe) PADA KEHAMILAN TRIMESTER DUA DI PUSKESMAS ALOOA GUNUNG SITOLIMEDAN. Jurnal Ilmiah Keperawatan Imelda, $5(1)$, 49-51. http://jurnal.uimedan.ac.id/index.php/JU RNALKEPERAWATAN/article/view/3 $07 / 310$
Notoadmodjo, Soekidjo. 2005. Meteologi Penelitian Kesehatan. Rineka Cipta.

Notoadmodjo, Soekidjo. 2008. Kesehatan Masyarakat. PT Rineka Cipta. Jakarta

Prasetyono, Dwi Sinar. 2008. 99 Pertanyaan Seputar ibu Hamil. Diva Press. Yogyakarta.

Saifuddin, Abdul Baru dkk. 2005. Ilmu Kebidanan edisi 9. Yayasan Bina Pustaka Sarwono Prawi Rohardjo. Jakarta.

Setiadi. 2007. Konsep Dan Penulisan Riset Keperawatan. Graha Ilmu. Yogyakarta.

Struddarth dan Brunner. 2005. Keperawatan Medikal Medah edisi 2. EGC: Jakarta.

Suheimin. 2007. Konsep Ibu Hamil. EGC. Jakarta.

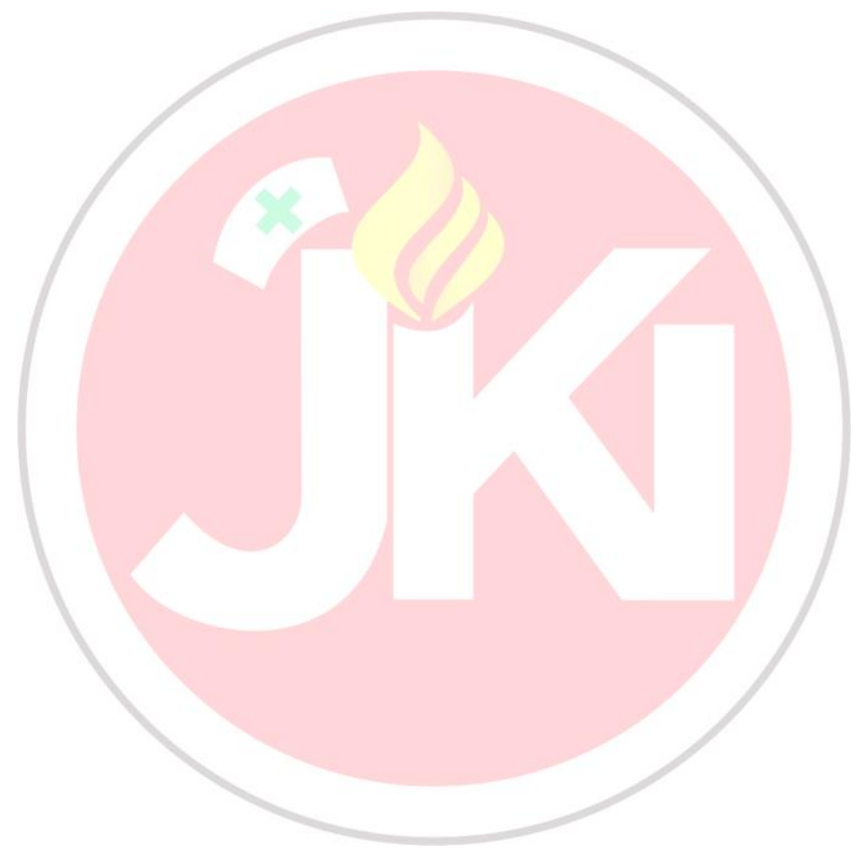

